\title{
Usability of a mobile application on diabetic foot self-care
}

\author{
Usabilidade de um aplicativo móvel sobre o autocuidado com o pé diabético \\ Usabilidad de una aplicación móvil en el cuidado con el pie diabético
}

\section{Antonio Dean Barbosa Marques' ORCID: 0000-0001-8969-1546}

Thereza Maria Magalhães Moreira' ORCID: 0000-0003-1424-0649

Thaís Vaz Jorge' ORCID: 0000-0002-5122-152X

Sara Maria Soares Rabelo' ORCID: 0000-0002-5451-1688

Rhanna Emanuela Fontenele Lima de Carvalho' ORCID: 0000-0002-3406-9685

Gilvan Ferreira Felipe" ORCID: 0000-0003-0674-4396

'Universidade Estadual do Ceará. Fortaleza, Ceará, Brazil. "Universidade da Integração Internacional da Lusofonia Afro-brasileira. Redenção, Ceará, Brazil.

How to cite this article: Marques ADB, Moreira TMM, Jorge TV, Rabelo SMS, Carvalho REFL, Felipe GF. Usability of a mobile application on diabetic foot self-care.

Rev Bras Enferm. 2020;73(4):e20180862. doi: http://dx.doi.org/10.1590/0034-7167-2018-0862

\section{Corresponding author:} Antonio Dean Barbosa Marques E-mail: antonio-dean@hotmail.com

EDITOR IN CHIEF: Dulce Aparecida Barbosa ASSOCIATE EDITOR: Marcos Brandão

Submission: 01-04-2019

Approval: 08-21-2019

\section{ABSTRACT}

Objectives: to assess the usability of an app prototype for diabetic foot self-care by an end user. Methods: a descriptive study that uses heuristic assessment of a hybrid app usability. Fifteen users of an outpatient diabetes care service in a capital of Northeastern Brazil participated in the study during April 2018. The usability measurement tool called Smartphone Usability questionnaiRE was applied. Results: the lowest score was 77 and the highest was 112 , with an average usability of 96.1 points. Usability was framed in the last two levels, 70 and 80 . Users now strongly agree (level 70) and fully (level 80) with the assessed items, which represents good usability of the apps prototype. Conclusions: the final product developed focuses on user needs and requirements, which can ensure usability based on effectiveness, efficiency and satisfaction triad.

Descriptors: Self-Care; Diabetes Mellitus; Telemedicine; Educational Technology; Diabetic Foot.

\section{RESUMO}

Objetivos: avaliar a usabilidade pelo usuário final de um protótipo de aplicativo para o autocuidado com o pé diabético. Métodos: estudo descritivo, de avaliação heurística da usabilidade de um aplicativo híbrido. Participaram 15 usuários de um serviço ambulatorial de atenção à pessoa com diabetes de uma capital do Nordeste brasileiro durante o mês de abril de 2018. Foi aplicado o instrumento de mensuração de usabilidade chamado Smartphone Usability questionnaiRE. Resultados: obteve-se como menor escore 77 e maior 112, com média de usabilidade geral de 96,1 pontos. A usabilidade foi enquadrada nos dois últimos níveis, $70 \mathrm{e}$ 80. Os usuários passam a concordar fortemente (nível 70) e totalmente (nível 80) com os itens avaliados, o que representa boa usabilidade do protótipo de aplicativo. Conclusões: o produto final desenvolvido tem foco nas necessidades e exigências do usuário, o que pode garantir a usabilidade, com base na tríade eficácia, eficiência e satisfação.

Descritores: Autocuidado; Diabetes Mellitus; Saúde Móvel; Tecnologia Educacional; Pé Diabético.

\section{RESUMEN}

Objetivos: evaluar la usabilidad del usuario final de un prototipo de aplicación para el autocuidado del pie diabético. Métodos: evaluación descriptiva, heurística de la usabilidad de una aplicación híbrida. Quince usuarios de un servicio ambulatorio de atención de diabetes en una capital del noreste de Brasil participaron en abril de 2018. Se aplicó el instrumento brasileño de medición de usabilidad llamado Smartphone Usability questionnaiRE. Resultados: el puntaje más bajo fue 77 y el más alto fue 112, con una usabilidad promedio de 96.1 puntos. La usabilidad se enmarcó en los dos últimos niveles, 70 y 80. Los usuarios ahora están totalmente de acuerdo (nivel 70) y totalmente (nivel 80) con los elementos evaluados, lo que representa una buena usabilidad del prototipo de una aplicación. Conclusiones: el producto final desarrollado se centra en las necesidades y requisitos del usuario, que pueden garantizar la usabilidad en función de la eficacia, eficiencia y satisfacción de la tríada.

Descriptores: Autocuidado; Diabetes Mellitus; Telemedicina; Tecnología Educacional; Pie Diabético. 


\section{INTRODUCTION}

Diabetes Mellitus (DM) currently affects 425 million adults worldwide. DM is projected to reach 629 million by 2045, i.e., there will be an estimated $48 \%$ increase in the number of people with the disease. When not properly administered, all types of DM can result in complications affecting many parts of the body, leading to frequent hospitalization, disability and premature death ${ }^{(1)}$.

Among the complications, the diabetic foot stands out, being the most feared by patients due to one-limb loss ${ }^{(1)}$. They are common and result in considerable, often recurring suffering, and are associated with a high mortality rate and a high cost of health, which makes it a serious public health problem ${ }^{(2)}$.

The number of hospitalizations for treatment of complicated diabetic foot and amputation is increasing compared to the other complications of $\mathrm{DM}^{(3)}$.

The exponential growth of DM patients has been a persistent concern of health professionals. In addition to health interventions, public policies and health programs recommend educating patients to actively participate in self-care ${ }^{(4)}$.

The use of mobile health apps may serve this purpose. These can provide personalized knowledge about the disease and bring about positive behavioral changes for self-care development for independent and effective management of $\mathrm{DM}^{(5)}$. Thus, considering the perpetration of mobile technology in the health field, companies and healthcare professionals have developed varieties of apps with emphasis on DM prevention and management ${ }^{(6)}$.

Usability is one of the key parameters for making a mobile app used and loved by users, as well as allowing users to achieve their specified goals. Efficiency, effectiveness and satisfaction are key factors that determine the user experience when involved with an app ${ }^{(7)}$.

DM is one of the leading chronic diseases of global health and exponential growth worldwide, with the main complication being diabetic foot. This can be prevented by very simple measures such as the simple daily assessment of feet by people with DM. Based on this context, it was proposed the creation of a multimedia app for daily care promotion for people with DM. Awareness of the theme arises from the professional performance of one of the researchers in this study as a stomatherapist nurse in home care, outpatient and hospital.

Given the above, the question is: what is the usability level of an app prototype for self-care with diabetic foot by an end user?

\section{OBJECTIVES}

To assess the usability of an app prototype for diabetic foot self-care by an end user.

\section{METHODS}

\section{Ethical aspects}

The study obeyed the ethical and legal precepts governing Resolution 466/12, which involves research conducted with humans from the Brazilian National Health Board (Conselho Nacional de Saúde) ${ }^{(8)}$. The study was approved by the Research
Ethics Committee of Universdade Estadual do Ceará, under Protocol 2,267,127 and Certificate of Presentation for Ethical Consideration (CAEE - Certificado de Apresentação para Apreciação Ética) 72351417.0 .0000 .5534$.

\section{Design, place of study and period}

This is a descriptive, heuristic and usability study of a hybrid app called "PedCare". We have proposed a mobile app to help DM and at-risk patients take care of the health of their feet.

This is a thesis deployment with mixed methods in sequential phases: 1) methodological study and 2) randomized controlled trial. Usability was analyzed by users when the app was in prototype phase. Sequential studies on the effect of this app were performed to verify its viability. It is noteworthy that the app is in the trademark and software registration phase and the other stages of the study are being published.

In order to ensure good app building practices, usability assessments are performed. There are several techniques to do this, ranging from informal assessment to usability testing analysis with user-class representatives. It is possible to reduce errors, increase productivity and safety when humans interact with the system ${ }^{(9)}$, which makes usability testing one of the main methods from the end user's perspective.

The study was conducted at the Integrated Center for Diabetes and Hypertension (CIDH - Centro Integrado de Diabetes e Hipertensão) in the city of Fortaleza, state of Ceará, Brazil, during April 2018.

\section{Population or sample; inclusion and exclusion criteria}

Fifteen CIDH users participated in the pilot study. It is recommended that the number of evaluators be a small group (from 3 to 5) for interface accuracy and assessment with the defined heuristics ${ }^{(10)}$. A priori, it was intended to compare usability in three distinct groups, but it was not possible to obtain statistical significance. They met the established criteria: age $\geq 18$ years; DM diagnosis; active registration at the health center; possession of a mobile device for personal use and familiarity; and skill with app use. It was measured by the maneuverability test with the prototype installed. People with marked functional dependence and/or cognitive impairment or with any difficulty that made the handling unfeasible, besides people with diabetic ulcer were excluded.

\section{Study protocol}

Participants were approached at the service while waiting for consultation with some multidisciplinary specialty, diagnostic tests or medication dispensation. They were briefed on the study, and those who were interested were taken to a private room where they explained the purpose of the study, presented the app's prototype feature explanations tutorial earlier, in PowerPoint format, designed on a tablet, and, then the app prototype. After consent for the study, the participants formalized their agreement by signing the Free and Informed Consent Term.

The "PedCare" mobile app prototype is a hybrid model that does not have the need for an internet connection to function, categorized as an advanced app by using features available on 
the installed mobile device. PedCare has 11 menus, 69 screens, based on User-Centered Design and HTML, CSS and JavaScript programming language to be compiled for Android and iOS platforms.

The user was offered the app running on smartphone or tablet, according to their preference. After handling on average 20 minutes, or when the user deemed the handling time to be adequate, the usability measurement tool called SURE (Smartphone Usability questionnaiRE) ${ }^{(10)}$, version (1.0) of the questionnaire was applied. SURE has 31 items, being specific to smartphones and developed through systematic literature review and use of Item Response Theory (IRT).

For each statement, the participant selected a response using degree of agreement on each criterion, with 1 - Inadequate, 2 - Partially Adequate, 3 - Adequate, 4 - Totally Adequate or NA - Not Applicable. The total score of the tool corresponded to the sum of all the answers. The total score of up to 124 points is calculated from the sum of the scores obtained in the items. The value is interpreted by the distribution ranges: level 30 (present a possibility to totally or partially disagree); level 40 (present possibility to agree); level 50 (fail to partially agree to strongly); level 70 (strongly agree); and level 80 (totally agree) ${ }^{(10)}$.

\section{Analysis of data, and statistics}

Data are presented through tables, being contrasted and discussed in the light of the literature on the subject. The variables were analyzed descriptively, considering simple frequency, percentage, mean, standard deviation and test mean.

The values obtained in the usability test were compared using the scores adopted by the SURE tool. Because it is based on the IRT, each evaluator's response to an item represents the probability as a function of the item's parameters and ability ${ }^{(10)}$, which allows data reliability.

\section{RESULTS}

The usability test consisted of 15 end users of the specialized care service, the majority (60.0\%) were women, with a mean age of 50.8 years, $40.0 \%$ single, $40.0 \%$ married, $60.0 \%$ had completed elementary school, with an average of 11.2 years of diagnosis of the disease and most (60.0\%) were using mixed therapy (use of hypoglycemic drugs and insulin), according to Table 1.

Table 2 presents the results obtained in the heuristic assessment of an app prototype usability by end users through SURE.

Table 3 presents each user's assessment level based on the sum of the scores proposed by the SURE tool.

Based on Table 3, the lowest score was 77 and the highest was 112 , with an overall usability average of 96.1 points. Thus, usability was framed in the last two levels, 70 and 80. That is, users strongly agree (level 70) and fully (level 80) with the assessed items, which represents good usability of the app prototype.
Table 1 - Audience characterization that analyzed app usability

\begin{tabular}{lll}
\hline Variables & F & $\%$ \\
\hline Age $(50.8 \pm 14.4$ years) & & \\
$\quad<40$ years & 03 & 20.0 \\
$40-<50$ years & 04 & 26.7 \\
$50-<60$ years & 04 & 26.7 \\
$\quad$ 60 years & 04 & 26.7 \\
Sex & & \\
Male & 06 & 40.0 \\
Female & 09 & 60.0 \\
Marital status & & \\
Single & 06 & 40.0 \\
Married & 06 & 40.0 \\
Widow(er) & 01 & 6.7 \\
Divorced & 02 & 13.3 \\
Schooling & & \\
$\quad$ Elementary School & 09 & 60.0 \\
$\quad$ High School & 02 & 13.3 \\
$\quad$ Higher Education & 04 & 26.7 \\
Time they know they have DM (11.2 \pm 5.4 years) & & \\
$\quad<5$ years & 06 & 40.0 \\
5-10 years & 03 & 20.0 \\
$\quad>10$ years & 06 & 40.0 \\
Type of treatment & & \\
$\quad$ Oral & 04 & 26.7 \\
$\quad$ Injectable & 09 & 13.3 \\
$\quad$ Oral and injectable & 60.0 \\
\hline
\end{tabular}

Table 2 - Distribution of participants' responses in each tool item

\begin{tabular}{lllllll}
\hline & \multicolumn{4}{c}{ Score } \\
Item & 1 & 2 & 3 & 4 & N/A
\end{tabular}

1. I found it easy to enter data in these applications. For example, using QR code, picklist, etc.

$010305-6$

2. When I make a mistake it is easy to correct it.

$-4371$

3. I found the help/tip given by the app to be helpful.

$-\quad 213-$

4. It was easy to find the information I needed.

5. I felt in charge using this app.

- 010311

6. I found the time it took to complete the tasks to be adequate.

- 010608

- 0906 -

7. It was easy to learn how to use this app.

- $060208-$

8. The sequences of actions in the application correspond to the way I usually perform them. For example, the order of buttons, data fields, etc.

9. It is easy to do what I want using this app.

030408

10. It was easy to navigate the application menus and screens.

11. The app meets my needs.

- $040506-$

12. I would recommend this app to others.

- $\quad 040901$

13. Even in a hurry I would be able to perform the tasks in this application.

$01030308 \quad-$

14. I found the app consistent. For example, all functions can be performed in a similar manner.

15. It is easy to remember how to do things in this app. $-0807$

16. I would use this app often.

30507

01030605 - 


\begin{tabular}{lllllll}
\hline & \multicolumn{4}{c}{ Score } \\
Item & 1 & 2 & 3 & 4 & N/A
\end{tabular}

17. The organization of menus and action commands (such as buttons and links) is logical, allowing you to easily - 040506 find them on the screen.

18. I was able to successfully complete the tasks using this app.

- $030606-$

19. I enjoyed using this app.

20. The app provides all the information needed to complete tasks clearly and understandably.

21. I found the app very complicated to use.

22. Symbols and icons are clear and intuitive.

23. I found the texts easy to read.

24. I found the application unnecessarily complex. I had to remember, research, or think hard to complete the tasks.

25. The terminology used in texts, labels, titles, etc. It is easy to understand.

26. I would need support from one person to use this app.

27. I felt comfortable using this app.

28. The app behaved as I expected.

29. I found it frustrating to use this app.

30. I found that the various functions of the application are well integrated.

31. I felt very confident using this app.

Note: this tool was developed by UFSC (a Brazilian university) in Portuguese and translated into English (in this article only), however it has not been validated yet.

Table 3 - Scores obtained from end-user assessment using the SURE usability tool

\begin{tabular}{ccc}
\hline User & SURE & Level \\
\hline 01 & 104 & Level 80 \\
02 & 99 & Level 80 \\
03 & 103 & Level 80 \\
04 & 101 & Level 80 \\
05 & 86 & Level 80 \\
06 & 97 & Level 80 \\
07 & 109 & Level 80 \\
08 & 84 & Level 80 \\
09 & 109 & Level 80 \\
10 & 112 & Level 80 \\
11 & 95 & Level 80 \\
12 & 77 & Level 70 \\
13 & 95 & Level 80 \\
14 & 87 & Level 80 \\
15 & 86 & Level 80 \\
\hline
\end{tabular}

\section{DISCUSSION}

Usability was framed at level 70 and level 80 by end users. At level 70 stratification, users strongly agree with the items. They find it easy to enter and correct data, they believe the product meets consumer needs. The features resemble available devices, have intuitive and interactive interface, texts are easy to read, have comprehension and accessibility in the language used, among other aspects. In the last level, users totally agree with all items and the help/tip provided by an app is helpful(10) . This fact allows us to infer that the app is pleasant to use and can be incorporated into everyday life.

Mobile app usability has attracted a lot of attention in the field of human-computer interaction, as well-designed apps can enhance user experiences ${ }^{(11)}$.

Thus, it is observed that the propagation of various usability assessment models has been introduced in the literature. These models are more general, which may not apply to any specific mobile app due to their complexities and lack of appropriate descriptions on how to choose usability measures such as usability dimensions, criteria and metrics ${ }^{(12)}$.

Other factors should be considered, such as exponential growth of apps, low quality availability, multiple categories, and different platforms. Therefore, in general, usability assessment models cannot measure the characteristics of these various apps because each app category has different functional and non-functional requirements. Thus, custom usability models may be required to assess these various apps ${ }^{(12)}$.

The HealthCare Information and Management Systems Society has developed guidelines to assess the usability of mobile health apps. This is a Likert scale to classify each criterion, which does not provide an indication of its quality, although the criteria were extensive and included usability engineering criteria to assess efficiency, effectiveness, user satisfaction, and platform optimization ${ }^{(13)}$.

Until the development of this study no specific tool was identified for the accuracy of mobile health app usability. A quality assessment scale called Mobile App Rating Scale - MARS(14) has been identified, but this scale is not yet translated and validated into Portuguese.

Usability assessment of mobile apps is still in its early stages. 26 usability models have been compiled for mobile apps, but these are unexplored and most of them have no proven effectiveness. This is a critical issue as existing usability guidelines are insufficient to design effective app interfaces due to peculiar characteristics and dynamic application context ${ }^{(12)}$.

Three experts conducted 66 app usability testing targeting people with DM over 50 . The total usability score was calculated from all categories, which were determined using a 5-point Likert scale. Most of the ratings ranged from 3.0 to 4.0, which corresponded to a moderate to good rating of apps, especially for those offering a small range of functions. Usability was categorized into three distinct parameters: Instant and easily understandable feedback 3,3; Intuitive usability 3.5; and Simple Recognition of ClickSensitive Areas 3.0 $0^{(15)}$.

Usability tests become increasingly essential before making app available to the end user. Prior to actual context applicability checks, this provides a technical baseline in which users are familiar with the potential of mobile technology. This allows users to provide richer feedback on functional requirements and use cases $^{(16)}$. 
One factor that can guarantee the usability of an app is its content. Based on this premise, the International Diabetes Federation has made recommendations for the development of DM app at four levels: individual, healthcare professional, politician and app developers ${ }^{(6)}$. In the individual field, the current app must meet basic needs and is in accordance with clinical practice.

\section{Study limitations}

As a limiting factor of this study, there is the restriction of the number of participants. Furthermore, it cannot be guaranteed that everyone has answered the questionnaire faithfully and with the utmost attention to each of the questions.

\section{Contributions to nursing, health or public policy}

Mobile health use can provide mechanisms to improve the efficiency and effectiveness of clinical care provided by nurses to promote foot care for people with DM. Thus, it would empower them to actively manage their health and to hold them accountable for their quality of life and health by providing information resources and reducing administrative burdens.

\section{CONCLUSIONS}

The test identified high usability of app prototype. End users have come to strongly and fully agree with the items analyzed, being a product developed focusing on user needs and requirements, which can guarantee usability, based on effectiveness, efficiency and satisfaction triad.

\section{FUNDING}

This study received funding through the Coordination for the Improvement of Higher Education Personnel (CAPES - Coordenação de Aperfeiçoamento de Pessoal de Nível Superior).

\section{REFERENCES}

1. International Diabetes Federation. IDF Diabetes Atlas. $8^{\mathrm{a}}$ ed. Belgium, 2017.

2. Jeffcoate WJ, Vileikyte L, Boyko EJ, Armstrong DG, Boulton AJM. Current challenges and opportunities in the prevention and management of diabetic foot ulcers. Diabetes Care [Internet]. 2018 [cited 2018 Sep 20];41:645-52. Available from: http://care.diabetesjournals.org/ content/41/4/645

3. Marques ADB, Silva LMS, Moreira TMM, Torres RAM. Association between hospitalization due to diabetes mellitus and diabetic foot amputation. Enferm Global [Internet]. 2018 [cited 2018 Sep 20]; 51: 258-266. Available from: https://revistas.um.es/eglobal/article/ view/286181/230521

4. Jia G, Jyu-Lin C, Whittemore R, Whitaker E. Postpartum lifestyle interventions to prevent type 2 diabetes among women with history of gestational diabetes: a systematic review of randomized clinical trials. J Women's Health [Internet]. 2016 [cited 2018 Sep 22];25(1). Available from: https://www.liebertpub.com/doi/abs/10.1089/jwh.2015.5262

5. Goyal S, Morita P, Lewis GF, Yu C, Seto E, Cafazzo JA. The Systematic design of a behavioural mobile health application for the selfmanagement of type 2 diabetes. Can J Diabetes [Internet]. 2016 [cited 2018 Sep 20];40:95-104. Available from: https://www. canadianjournalofdiabetes.com/article/S1499-2671(15)00496-7/abstract

6. Rose KJ, Petrut C, L'Heveder R, Sabata S. IDF Europe position on mobile applications in diabetes, Diabetes Res Clin Pract[Internet]. 2017 [cited 2018 Sep 22]. Available from: https://www.ncbi.nlm.nih.gov/pubmed/28951337

7. Kumar DS, Purani K, Viswanathan SA. Influences of'appscape' on mobile app adoption and m-loyalty. J Retail Cons Serv[Internet]. 2018 [cited 2018 [cited 201820 Sep 23]. Available from: https://www.researchgate.net/publication/327287073_Influences_of_appscape'_on_mobile_app_adoption_and_mloyalty

8. Conselho Nacional de Saúde (BR). Resolução n 466, de 12 de dezembro de 2012. Diretrizes e Normas Regulamentadoras de Pesquisas Envolvendo Seres Humanos. Diário Oficial [da] União, Brasília, DF, n. 12, 13 de junho de 2013. Seção 71, p. 59.

9. Shackel B, Richardson SJ. Human Factors for Informatics Usability. Cambridge University Press New York, NY, USA; 2008.

10. Wangenheim CG, Borgatto AF, Nunes JV, Lacerda TC, Oliveira RJ, Krone C, et al. Sure: uma proposta de questionário e escala para avaliar a usabilidade de aplicações para smartphones pós-teste de usabilidade. 6ta. Conferencia Latinoamericana de Diseño de Interacción [Internet]. 2014 [cited 2018 Sep 20];19-22. Available from: http://bibliotecadigital.uca.edu.ar/greenstone/cgi-bin/library. cgi? $\mathrm{a}=\mathrm{d} \& \mathrm{c}=$ Ponencias\&d=sure-proposta-questionario-escala

11. Hoehle H, Aljafari R, Venkatesh V. Leveraging Microsoft's mobile usability guidelines: Conceptualizing and developing scales for mobile application usability. Int J Human-Comp Stud. 2016;89:35-53. doi: 10.1016/j.ijhcs.2016.02.001

12. Zahra F, Hussain A, Mohd H. Usability evaluation of mobile applications; where do we stand? The 2nd International Conference on Applied Science and Technology. 2017. doi: 10.1063/1.5005389

13. Health Care Information Management Systems Society. mHIMSS App Usability Work Group. Selecting a mobile app: Evaluating the usability of medical applications. 2012[cited 2018 Sep 20]. 32p. Available from: https://www.himss.org/ selecting-mobile-app-evaluating-usability-medical-applications-0

14. Stoyanov SR, Hides L, Kavanagh DJ, Zelenko O, Tjondronegoro D, Mani M. Mobile app rating scale: a new tool for assessing the quality of health mobile apps. JMIR mHealth uHealth [Internet]. 2015 [cited 2018 Sep 20];3(1):e27. Available from: https://mhealth.jmir.org/2015/1/e27/ 
15. Arnhold M, Quade M, Kirch W. Mobile Applications for diabetics: a systematic review and expert-based usability evaluation considering the special requirements of diabetes patients age 50 years or older. J Med Internet Res [Internet]. 2014 [cited 2018 Sep 22];16(4):e104. Available from: https://www.jmir.org/2014/4/e104/

16. Vélez O, Okyere PB, Kanter AS, Bakken S. A usability study of a mobile health application for rural ghanaian midwives. J Midwifery Womens Health [Internet]. 2014 [cited 2018 Sep 23];59(2):184-91. Available from: https://www.ncbi.nlm.nih.gov/pmc/articles/PMC3976680/ 